\title{
22. A Business of One or Nurturing the Craft: Who are You?
}

\author{
Ilana Gershon and Mark Deuze
}

\begin{abstract}
If you want to be successful as a professional media maker, you have to think of yourself as a 'business of one': always managing, promoting, and performing yourself as a brand. This is a truism throughout all media industries. However, such constant self-branding comes at a cost. This chapter discusses the origin of self-branding and offers an alternative way of finding work in media by focusing on craftsmanship.
\end{abstract}

\section{Introduction}

Especially since the early 2000s, being a professional media maker has meant being conscious of the fact that you have and are a personal brand. Branding yourself has become a ubiquitous task. The reason for this shift may seem obvious: new communicative technologies. Without technologies such as Twitter, Facebook, or earlier predecessors like MySpace, media workers did not have the tools to brand themselves. Yet, suggesting that journalists, advertising creatives, game developers, and all the other professionals across the media industries brand themselves because it is now technologically possible to do so overlooks the history of self-branding as a perceived prerequisite for success in the media industries, and especially bypasses a deeper question: why would anyone think that this was a good idea or a necessary practice in the first place?

Media workers - such as professionals in film and television, advertising, and music - to some extent have always adopted branding tactics for themselves: creating and managing a certain persona, doing the emotional labour necessary in largely informal and reputation-driven working environments to suggest a persona, performing this identity dutifully in order to make it work. The twin developments of precarization of work in the media industries and the rise of digital media have amplified and accelerated the branding trend, often raising the level of self-promotion to stressful levels.

However, branding is not an inevitable practice - it is not even all that measurably effective. In this chapter, we argue that the notion of branding accompanied a shift in how people understand the nature of work and, more specifically, a shift in how people understood what it meant to work for others. People are now expected to 
view themselves as a business of one (Lane, 2011), seeking to enter into business alliances with others. The employment contract is now seen as a business-to-business contract in which you, as a business, are contracted to provide temporary solutions to another business's market-specific problems (Gershon, 2017). In the case of a professional media maker, this typically means a temporary contract to provide content to a media outlet.

This metaphor, whereby you should think of yourself as a business, was, however, developed to solve a conceptual problem, not a practical problem that actual workplaces face. It was supposed to help bridge the gap between an increasingly dominant philosophy advocated by economists such as Frederick Hayek, Milton Friedman, and others of the Mont Pelerin Society, and how people actually live their lives in the labour market. It may just have been a solution for a conceptual problem, but it has had all sorts of implications for how actual workplaces are run, and how people understand career strategies, including the widespread belief that everyone should have a personal brand.

\section{A business of one}

Frederich Hayek (1899-1922) was an Austrian economist who had a conviction: that markets were the best form of spontaneous order for the modern world. Nowadays, many people share this conviction, in part because Hayek and his followers became so influential. But, at the time that Hayek and his circle began to argue for this position, it was a much more controversial and minority ideological position to take. Hayek was responding both to Soviet communism and Fascism, two systems that rely on centralized planning to manage the economy. For Hayek, centralized economic planning was a recipe for disaster. As a basic tenet, he held that human beings are too flawed to be able to plan a complex modern economy. There was no way that a single human being, or even group of human beings, could competently handle the informational complexities of modern economic systems. Given that humans were too limited to be able to plan without imminent disaster, having the market organize large-scale production and distribution was the best alternative available.

At the same time, Hayek understood that markets did not emerge naturally, they are constructed and have tendencies towards monopoly and other business practices that could undercut forming a level playing field. This is the primary reason why governments should exist - government laws and regulations are necessary to ensure that markets function well. Governments should not be providing services to its citizenry such as public transportation or a postal service - Hayek believed these services are most efficiently managed by private interests. Also, governments 
should not be providing forms of welfare to its citizens, since welfare undercuts how the market allocates value and introduces too much centralized planning. Instead, what governments should focus on, according to Hayek, is organizing markets well and keeping them functioning to promote competition, and thus innovation. Because market competition is the goal, arbitrarily curtailing this competition through tariffs or other nationalist strategies for undercutting a global market was also deeply undesirable. Hayek wanted a truly global market.

This approach to markets and governments, commonly called neo-liberalism by its critics, has become the dominant way in which the global economy is organized. As this theory moved off the page and the blackboard, people who wanted to live according to neo-liberal principles ran into a basic problem. Neo-liberalism implies a specific way of being a capitalist, and not one that everyone agrees with, even if they are committed to capitalism in general. So, as neo-liberalism became more widely accepted, its practitioners had to figure out how to change the infrastructures and the ways of talking about capitalism. To make a neo-liberal approach persuasive, they had to figure out how to live as a neo-liberal. It turns out that there are all sorts of social dilemmas in daily life that are not addressed by saying: 'The market is the best way to organize or determine value.'

True, Hayek understood that he needed to explain what kind of person you had to be in order to engage with the market in the way he wanted. But he never developed a particularly good model for making complicated decisions like deciding who to hire for a job opening, or how to fashion a career over a lifetime. Other economists, like Gary Becker who coined the idea of human capital, had to come up with more concrete ways to understand how people should analyse everyday interactions using a neo-liberal logic. They began to talk about how people need to think about investing in themselves, viewing themselves as an asset whose value only the market could effectively determine. As critics such as Zygmunt Bauman (2007) note, this rationale of 'no consumer unless a commodity' pressures people to think of themselves as a product that needs constant upgrading and development in order to remain current, relevant, and noteworthy for an otherwise unfeeling market. Only when you attract attention and appreciation - for example expressed in a salaried job or paid assignment - can you effectively participate in society. Throughout the second half of the twentieth century, a general consensus emerged that people should indeed view themselves as a business - a bundle of skills, assets, qualities, experiences, and relationships that constantly had to be managed and enhanced.

Workers, especially in the media and the cultural and creative industries, are told to think of themselves as a business in a context in which neo-liberal approaches to businesses have also changed the ways in which a company determines its actual value. Before a neo-liberal perspective became entrenched, companies might be 
seen as providing a wide variety of benefits to a large number of constituents - to upper management, to employees, to the local community, as well as to shareholders. Many of these benefits were long term. But as the market value began to be seen as the primary and often only way to measure a company's value, increasing the value to shareholders began to be the principle goal for companies. Companies started to focus on quarterly earnings and stock prices as the sole measure of success.

This changed how companies treated employees. To keep stock prices high, companies, for example, had to pay their employees as little as possible. Professional associations such as the National Union of Journalists in the UK and the Media Entertainment \& Arts Alliance in Australia have noted that media workers often report they feel more like someone that costs their employer money than a valued employee. Furthermore, under neo-liberal policies companies are increasingly seeking to have as temporary a workforce as their particular business can allow. The less permanent the workforce, the easier it is to expand and contract in response to short-term demands and market fluctuations. Public policies have followed suit, making it easier for companies to fire employees, expanding the various ways in which a company can sub-contract and outsource labour, as well as providing incentives to workers to become self-supporting free agents (or 'entrepreneurs').

\section{The consequences of neo-liberalism}

When companies arrange themselves according to Hayek's world view, it relatively quickly leads to precarious work conditions for employees - a process additionally facilitated by a decline in collective organization among (media) workers. What companies need are not workers to whom they have clear obligations to foster long-term relationships through pensions and similar incentives. Instead, they need professionals who work dependably, and in many cases, long, intense hours to finish short-term projects. They want employees who no longer expect long-term commitments from their place of work. This form of precarity means that workers have to figure out how to get contract after contract - a career becomes a string of jobs or contracts.

In practice, media workers have found that this typically means they are constantly searching for a job - that they now have two jobs, the contract they are currently working on and the job of looking for the next contract. But what does looking for the next job actually consist of? In part because it is such a logical extension of the self-as-business metaphor, always looking now involves always branding oneself. This notion of personal branding became popular when Tom Peters, a motivational speaker and management consultant, wrote 'The Brand Called You' for FastCompany in 1997, in which he explicitly connected the dots between 
the self-as-business and branding oneself: 'We are CEOs of our own companies: Me Inc. To be in business today, our most important job is to be head marketer for the brand called You' (Peters, 1997). This take caught on - it certainly captured the emerging neo-liberal spirit of the time.

Now part and parcel of having a career in the media is understood to be regularly crafting your personal brand by (for example) figuring out three or four words that reflect an authentic self (consider for example the space for a bio on a Twitter profile); making sure that all your online and offline interactions are consistent with these terms; spending considerable time managing and interacting through various online profiles (LinkedIn, Twitter, Facebook, and so on); curating what comes up when people (especially prospective employers or clients) Google your name; and so on and so forth. All of this, of course, in addition to creating excellent work and building a reputation among businesses and peers as a desirable hire. If all of this sounds time-consuming, it is. Indeed, for professional media makers these days, the freedom of being able to create work about what you are most interested in, and thus what you are framing as your core brand attributes, comes at the price of no longer having free time.

Now that self-branding is seen as essential for success, this also becomes an avenue for explaining failure that allows media workers to overlook the changes to the labour market - generally attributing a lack of assignments or doing too much underpaid or even non-paid work to a host of factors other than critically reviewing the system as a whole. Self-employed media workers are blaming themselves in a way parallel to what Ofer Sharone says unemployed white-collar Americans do. In his book, Flawed System/Flawed Self (2013), Sharone critiques the widespread scholarly belief that Americans are culturally individualistic, and thus prone to see their successes and failures as the result of their own actions, instead of as a result of structural shifts in the labour market. As an example, when an American cannot get a permanent job managing a call centre, he will supposedly claim it is his own fault, not that those jobs were all outsourced to India and the Philippines because of labour costs and government policies.

Sharone notes that when Americans blame themselves, it is not due to cultural blinders on their part, but rather a perfectly reasonable response to how the hiring ritual is structured in the US. He points out that in the US, job seekers are often rejected for an especially nebulous reason - not being a 'cultural fit'. This amorphous term is widely understood as a flexible code for concealing the concrete and often politically charged reasons a hiring committee chooses someone else. While in actuality a hiring manager may have been concerned that a job seeker had spent too little time working at their last couple of jobs, or too much time (both of which tend to be structurally specific issues having to do with those workplaces), the explanation the person will receive for the rejection is the more ambiguous 
'not a cultural fit' reason. Or, people are told that networking is the primary way to get a job these days, in part because applicant tracking systems and recruiters screen out so many good candidates. Yet, this advice tends to leave vague what kinds of networking - what activities and what connections - are necessary. People who view themselves as introverted or reluctant to make relationships openly instrumental see their failures to network 'properly' (however ill-defined that may be) as the cause of their unemployment, not employers' poor sorting mechanisms or biases inherent in the top-down system. When given these nebulous explanations enough times, people will start blaming themselves for why they don't have a job.

Media professionals are caught in a similarly ambiguous trap. They are told that in order to succeed, they must work two jobs simultaneously: looking for the next job constantly, that is, self-branding, while also doing the job at hand. At the same time, the job market for self-employed media makers sends out contradictory and ambiguous messages, as opaque for them as 'cultural fit' is for the American job seeker. As a result, they frequently understand failure in terms of personality traits. People who are reluctant to market themselves or not particularly talented at those set of tasks are seen as producing their own career failures.

Freelance media professionals do not tend to suggest that there are structural problems with how the labour market is constructed. Nor do they point out that what makes one good at getting a job is not necessarily what makes one good at doing a job. Instead, they blame themselves for their reluctance to brand themselves, or they blame consumers for not appreciating their art. They might perhaps even blame a specific company or executive for overlooking their talent, but it is rare for them to critique the way professions such as journalism or film and television production are structured. Even if they do, it is generally not considered good form to complain about such arrangements on the job, and the degree of collective organization - which would enable them to act on such grievances - tends to be quite low among media workers.

\section{Passion as a panacea}

Job insecurity, self-branding, and passion go hand in hand these days. The emotions you are supposed to feel for your work change when you start seeing yourself as a temporary employee making a career from a long string of jobs. Companies used to try to foster company loyalty in every way they could, since this provided them with a steady bank of workers already familiar with how the company worked. It also meant that the company had people maximally committed to having the company do as well as possible, often with a lot of experience about how the company had 
done things in the past. But when companies decided to do away with company loyalty, a new emotional connection to work had to be found as a replacement.

While there were a number of possible emotions one could turn to, the general consensus in creative careers such as in the media has been that everyone should feel passion for their work. This is consistently the advice any media professional will give those vying for a spot in their line of work. It seems irrelevant what the job actually is, and whether the job does, in fact, require that someone feels strongly about who they are working for or what kind of work they are expected to do in order to do it well. Since company loyalty is no longer around to guarantee committed workers, passion is now supposed to be the driving force.

Intriguingly, this passion people are supposed to feel is restricted to the tasks at work or to learning certain skills, tracking down leads or becoming better at capturing the most compelling shot. There are many parts of a job that one is never asked to feel passion for, and telling enough, most of these aspects would be the ones that keep you committed to a particular company. So people tend not to express passion for working with particular people (unless that kind of passion is supposed to be performed, such as in 'making of' showreels as part of the promotional campaigns for motion pictures). Media makers also generally do not talk about feeling passion for making the company they work for well-respected among other companies. Instead, they are only supposed to feel passion for the duties of their job role, duties that they could theoretically perform at any media company. Passion is reserved for the tasks that they do (or learn to do) and for the solutions that they might develop for market-specific problems that the company faces. All too often, the market-specific problems that employees talk about being captivated by are problems that a range of companies might face. They are not specific to that particular company. In short, work based on passion is focused on all the tasks that only involve the worker's career trajectory (and narrative thereof), and none of the tasks that solely involve the company's well-being (Gershon, 2017).

Focusing on feeling passion for lucrative tasks makes workers more mobile. When the main reason to work somewhere is because you feel passion, it is all too easy to quit because you have stopped feeling passion. Passion, furthermore, is an exceptionally vague qualifier, and certainly is not necessarily synonymous with either a job well done, or any particular talent or exceptional ability. It is also much harder to develop a substantial critique of the industry you are in if what brings and keeps you at work inside this industry is your own, individual, and intimate passion - you would end up being critical of the very thing that connects most deeply to who you (think you) are. Finally, passion is a rather self-centred focus - if not obsession - more often than not bypassing (caring for) others. 


\section{Conclusion: Craftsmanship as an alternative focus}

We have been suggesting that there is a price to pay for imagining the labour market as full of businesses - some shaped like people and some shaped like companies - all entering into temporary alliances with each other. Many media makers now work in a situation where they compete with each other to tell their stories rather than in a situation where media companies compete to nurture and support their talent. As a result, the price is more often paid by (and steeper for) media workers in temporary contracts trying to craft a career than by the media companies organizing and benefiting from this temporary labour pool (Deuze, 2007, 2011).

But is there an alternative path that media workers can follow to live more humane lives that doesn't involve the very time-consuming and messy work of starting a revolution or quitting this line of work entirely? We want to suggest here a quieter path towards reform, reviving an older way of understanding what it means to be a worker and its accompanying practices: seeing yourself as a craftsperson instead of a business. Scholars such as Jean Lave, Richard Sennett, and Etienne Wenger have analysed the social practices that make being a craftsperson, including apprentices, a more tolerable way forward (Lave \& Wenger, 1991; Sennett, 1998, 2009).

What would thinking of oneself as a craftsperson instead of a business involve? First and foremost, you would see yourself as a maker - someone whose creativity and skill produces texts, images, and objects that can change the world for the better. Doing a task well for its own sake, for the satisfaction of showing mastery, is a very different goal than doing a task solely for profit, and often someone else's profit. As a craftsperson, you are constantly exploring your capacities alongside other people who have different degrees and areas of mastery as well. One editor might be especially good at figuring out how to fashion a catchy phrase, and be able to teach you how to do this better. Another editor might be especially good at knowing what information a reader needs and when to grasp a complex situation. At the same time, as a craftsperson, you are always helping other people become better as well - you are enmeshed in relationships of apprenticeship, co-working, mutual support, and mentoring that make the challenges of working together more valued than the efforts of individually marketing oneself. Part of how you are known as someone who is desirable to work with will be based on how well you tend to your relationships and how well you encourage other people in their pursuits.

Attending to one's reputation, in other words, can be a more social, more ethical, and more nuanced focus than promoting one's brand. The difference lies in the orientation toward the craft or the business. A business reputation is all about performance: not necessarily being good at what you do, but creating and maintaining the image of being good (whatever 'good' may be in the particular context of the project at hand). A craft reputation is about being renowned for the quality of 
your work and the extent to which you take pleasure from honing your craft (and that of your fellow workers). Being a craftsperson instead of a business also leads more easily to forms of collective organization, whether through unionizing, joining professional associations, or maintaining various networks offline and online. A craft orientation eschews a form of competition that undercuts other media workers in pursuit of work opportunities, it opens up space for collaboration and co-creativity.

There are different ways to understand the work that media makers have to do in order to make it work. Part of this involves not just doing good work, but also being known for doing so. Incessant self-branding is just one route for gaining such recognition, and a deeply problematic one that takes up lots of people's time and without clear cut results. But it takes more than media makers just saying: 'Right, I won't worry about branding myself anymore'. It also means that media companies should consciously decide to retain and nurture talent, rather than just managing to the bottom line. It means valuing other people for the quality of their work and the ethical ways they conduct themselves as colleagues. It involves caring for the (collaborative, co-creative) work and for fellow workers rather than a self-centred focus on finding one's passion.

People participate in making branding seem like an obvious and desirable route at many different moments in the workplace. It is time to cultivate the craft instead.

\section{Further reading}

- Case: Three case studies on how the working conditions within the cultural and creative industries are affectively experienced - Cantillon \& Baker (p. 287)

- Context:The various new forms of value which circulate in the media industries, resulting from different ways in which media makers and users value media - Bolin (p. 111)

- Contrast: How freelancers in the media industry are collectively working to protect their rights and improve their position - Cohen (p. 235)

\section{References}

Bauman, Z. (2007). Consuming Life. Cambridge: Polity Press.

Deuze, M. (2007). Media Work. Cambridge: Polity Press.

Deuze, M. (ed.) (2011). Managing Media Work. London: SAGE Publications.

Gershon, I. (2017). Down and Out in the New Economy: How People Find (or Don't Find) Work Today. Chicago, IL: University of Chicago Press.

Lave, J. \& Wenger, E. (1991). Situated Learning. Cambridge: Cambridge University Press. Sennett, R. (1998). The Corrosion of Character: The Personal Consequences of Work in the New Capitalism. New York: W. W. Norton and Company. 
Sennett, R. (2008). The Craftsman. New Haven, CT: Yale University Press.

Sharone, O. (2013). Flawed System/Flawed Self:Job Searching and Unemployment Experiences. Chicago, IL: University of Chicago Press. 